\title{
TV/Series
}

18 | 2020

Séries et espace

\section{Walking in (a) Bordertown: Sorjonen, Liminality, and the Spatial Imaginary of Lappeenranta}

Robert A. Saunders

\section{(2) OpenEdition}

Journals

Electronic version

URL: https://journals.openedition.org/tvseries/4877

DOI: 10.4000/tvseries.4877

ISSN: 2266-0909

Publisher

GRIC - Groupe de recherche Identités et Cultures

\section{Electronic reference}

Robert A. Saunders, "Walking in (a) Bordertown: Sorjonen, Liminality, and the Spatial Imaginary of Lappeenranta", TV/Series [Online], 18 | 2020, Online since 15 September 2020, connection on 21 September 2021. URL: http://journals.openedition.org/tvseries/4877 ; DOI: https://doi.org/10.4000/ tvseries.4877

This text was automatically generated on 21 September 2021.

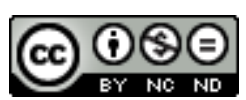

$T V / S e r i e s$ est mis à disposition selon les termes de la licence Creative Commons Attribution - Pas d'Utilisation Commerciale - Pas de Modification 4.0 International. 


\title{
Walking in (a) Bordertown: Sorjonen, Liminality, and the Spatial Imaginary of Lappeenranta
}

\author{
Robert A. Saunders
}

1 While Nordic noir television - a screened genre that evolved from the crime-based literary tradition of Scandinavian noir - is primarily defined by Danish and Swedish offerings such as The Killing (DR1, 2007-2012) and Wallander (TV4, 2005-2013), Finnish programming is increasingly finding success beyond the country's borders through the transnational digital distribution platforms. Sorjonen (Yle, 2016- ) - or as it is known internationally, Bordertown - is perhaps the best example of this trend, having been distributed with subtitles in multiple languages via Netflix. Set in the idyllic lakeside resort of Lappeenranta, Bordertown centres on Detective Inspector Kari Sorjonen (Ville Virtanen) following his relocation there in the wake of his wife's illness. Hoping to leave major crimes behind in the capital Helsinki, Sorjonen is soon investigating horrific murders and gruesome events. The criminal networks he uncovers often extend far beyond his new home, indicting hitherto respected members of the community and the state in the process (therein keeping true to the traditions of the TV genre and its pulpy predecessor). Indeed, this is because the town is Finland's closest major settlement to Saint Petersburg, placing picturesque Lappeenranta at the nexus of illicit flows that link Russia to the European Union (EU). ${ }^{1}$ While Bordertown generally avoids the crass Russophobia of many other screened geopolitical interventions ${ }^{2}$, the series does deploy its setting's geopolitical "in-betweenness" to engage with a variety of challenges to Europe. While the Kremlin may not be behind every criminal act, Finland's nearby neighbour stalks the narrative, which features two important Russian-born and Russophone characters: Detective Constable Lena Jaakkola (Anu Sinisalo) and her daughter Katia (Lenita Susi). As border-crossers, these two staples of the series consistently remind the viewer of the town's status as a liminal zone. As a result, Bordertown can be comfortably situated within a growing suite of Nordic noir series including Midnight Sun (SVT, 2016) and The Bridge (SVT1 and DR1, 2011-2018), which weave narratives of in-betweenness, marginalised characters, and 
liminal landscapes (or what I refer to as edgescapes) together to complicate the notion of a Nordic uniformity and perfection.

Drawing on my previous work on geopolitical television ${ }^{3}$ and imagining cities through screened representation ${ }^{4}$, this essay interrogates Bordertown's use of a real place, i.e. Lappeenranta, to sculpt a geographical imaginary that can tell a geopoliticallyinformed story through its narrative, as well as its natural and urban landscapes. Similar to other Nordic noir series, which rely on substantive engagement with the natural environment as well as human-built geographies ${ }^{5}$, Bordertown is visually dependant on its chosen setting (in this case, Lappeenranta). As a result, the series features extensive shots of Lake Saimaa, its islands, and the boreal wilderness surrounding the city, as well as the giant sawmill at the outskirts of town, the welltouristed harbour, and the compact city centre. The sites where dead bodies are found often link to the local milieu, flagging up the importance of the place on its denizens (and especially humanity's perfidy and capacity for violence). Focussing on a variety of elements from water to wind turbines, I follow Paasi's admonition that "boundaries exist and gain meanings on different spatial scales ${ }^{6 "}$. Consequently, this essay examines a variety of sites/sights (i.e. the body, border, state, land, and nation) to examine the series' narrative, dramaturgical, and visual scaping of a chimerical "border town" that maps on to the "real" city of Lappeenranta. Filtered through Bordertown's visual rhetoric of Lappeenranta and informed by the author's Bordertown TV-Series Walking Tour and content provided by the tour operator and the series' showrunner, this article synthesises approaches from cultural geography, critical IR, and television studies to assess the series' intervention in the everyday, lived, and embodied geopolitics of this south-eastern Finnish city. This is done in an attempt to reflect on the notion that "tourism landscapes are spaces where translocal social realities merge and rearticulate geopolitical assemblages ${ }^{7 "}$.

In terms of its structure, this article begins with a brief overview of Finland's eastern border regions and Lappeenranta's premiere position as "contact zone" within a larger space of "in-betweenness" vis-à-vis the Russian Federation. I then summarise the series' narrative arc, paying close attention to the liminal and transnational elements that characterise the programme. From here, I shift to how the Bordertown walking-tour of Lappeenranta engages the series' built-world ${ }^{9}$ via emplacing the tourist in the town, and its natural and human-built environments. Here I reflect on my own experiences as the "first" English-language guest to undertake the excursion..$^{10}$ In the final section, I make use of Gillen and Mostafanezhad's method for unpacking the geopolitics of the tourist experience to interrogate the role of televisual landscapes as meaning-making manipulations of the distant gaze ${ }^{11}$. As an interdisciplinary undertaking, this essay draws on approaches from a number of fields, including television studies, popular geopolitics, and place-making/branding. In keeping with the aims of this special issue on geographic constructions of places through televisual mediations of spaces, this intervention makes a contribution to the literature of geographical imagination ${ }^{12}$ in its empirical analysis of the screened space of Lappeenranta as a zone of liminality ${ }^{13}$. However, this article also aims to provide a tentative model for the imagineering of other "real-world" places through their use in fictional television series (especially crime drama), by examining the connections between society, tourism, and the output of national public broadcasters like Yle. My overall goal of combining these approaches is to provide a tentative assessment of how screened visualisations of national 
territories are contributing to transnational geopolitical codes in a world defined by Fremdbebilderung or the "state of being 'totally engulfed by foreign images"14".

\section{Finland, a Country at the Edge of Europe and on the Threshold of Russia}

4 Situated at the extreme north-eastern corner of the European Union, and possessing a 1,340-kilometre border with the Russian Federation, Finland ranks as one of the continent's defining liminal spaces. Not insignificantly, this border now runs through the Petsamo, Salla and Karelia, regions that were once part of an independent Finnish Republic. As Paasi points out, such boundary-based liminality is not a fixed reality, but instead the outcome of sustained social and discursive practices (which include screenings of the frontier) ${ }^{15}$. When juxtaposed with Russia, Finland functions as "Europe" counterpoised against the "non-European" space of the Russian Federation. Yet, Finland - when denuded of its Russian other - becomes a grey zone at the extreme periphery of Europe proper, a "double negative" of not this and not that ${ }^{16}$. As a country whose titular nationality speak a non-Indo-European language ${ }^{17}$, Finland has long been viewed as marginal even with a region that was once dismissed as Ultima Thule and is still at the "edge" of Europe ${ }^{18}$. Lacking natural resources (beyond an ample supply of timber and reindeer), Finland entered the twentieth century as a nation locked within an imperial system that granted it subjects a bevy of privileges denied to the average Russian, but which did little to salve its people's aspirations for independence. The February Revolution provided Finnish nationalists with an opportunity for change, one which they translated into reality with the coming of the Bolshevik Revolution. After severing ties with Russia and a bloody civil war that pitted "Reds" against "Whites," the Finnish republic emerged as the septrional bulwark of the interwar cordon sanitaire that ostensibly shielded western European democracies from the influence of Moscow and the Communist International (Comintern). In World War II, the Finns fought two wars with their eastern neighbour, resulting in the aforementioned ceding of territory to the Union of Soviet Socialist Republics. Independent and neutral, Finland - as a country in a "disputed camp between Eastern and Western blocs" ${ }^{19}$ " thus emerged as a "Nordic country" with "eastern European problems ${ }^{20 "}$, summed up neatly in the coining of the (American) geopolitical concept of "Finlandisation" ${ }^{21 "}$.

5 Realpolitik dictated that Finland walk a fine line during the early Cold War, resulting in what some have labelled a form of hegemony that mirrored US influence over its North Atlantic Treaty Organisation (NATO) allies during the Cold War ${ }^{22}$. In order to preserve democracy at home, Helsinki hewed towards the Soviets in international affairs, rejecting Marshall Plan funds and observing a strict form of non-alignment and deference to Soviet actions on the international stage. ${ }^{23}$ With the dissolution of the USSR and the end of a continent divided by an "Iron Curtain," Finland rapidly moved to join the European Economic Community in an attempt to find new markets to compensate for losses associated with Russia's rapid economic contraction after 1991. As part of this integration, Finland also began to develop a bolder posture in terms of its sovereignty, openly recognising that - despite official statements to the contrary its security faced threats from the east and not the west. At the dawn of the millennium, modest, non-confrontational Finland emerged on the world stage as a dynamic, technologically-savvy powerhouse at the edge of the Arctic, driven in good part by the 
mobile phone manufacturer Nokia's global success. Over the past two decades, the small, ${ }^{24}$ homogenous ${ }^{25}$ republic has consistently topped international rankings across a broad array of measurements, but being especially successful in the areas of prosperity, education, stability, press freedoms, personal liberty, safety, governance, low corruption, global development policies, social justice, human rights, and human wellbeing ${ }^{26}$.

6 While Russia's role in Finnish affairs greatly diminished in the post-Soviet era, it did not disappear altogether. In the new millennium, a resurgent Russian Federation, buoyed by rising oil and natural gas prices, once again came to serve as a key component of the Finnish economy, especially in the border regions. The south-eastern city of Lappeenranta thus re-emerged as a vibrant gateway to and from Russia (a position that it assumed from Vyborg following that city's annexation as part of the 1947 Paris Peace treaties). Tourism, which has its origins in the first spa being established in the city in 1824 , is probably the most visible aspect of this shift (or return to form); ${ }^{27}$ however, industries associated with cross-border exchange and the transnational service sector also came to form strands of this nexus of trade and the movement of people. Indeed, Finland represents one of only a few European countries (alongside Montenegro and Cyprus) where Russian-language proficiency is on the rise rather than in decline ${ }^{28}$. However, the severe contraction in the value of the rouble following international sanctions levied on the Russian Federation following the 2014 annexation of Crimea have proved detrimental to the city's economy. As the flow of Russian tourists, high-end shoppers, and arbitrage merchants waned, Lappeenranta's ubiquitous Russian-language signage has become somewhat ironic in recent years, providing a haunting reflecting of the unpredictable power of geopolitics far from the site of any "intervention." It is in this protean milieu that the imaginary of Bordertown is built.

\section{A Précis of Bordertown (Seasons 1 and 2)}

7 Sorjonen premiered on the public broadcaster Yle's TV1 on 16 October 2016, being watched by over one million viewers, therein setting a record for a Finnish series (see Image 1). 
Image 1. The Title Sequence from Bordertown.

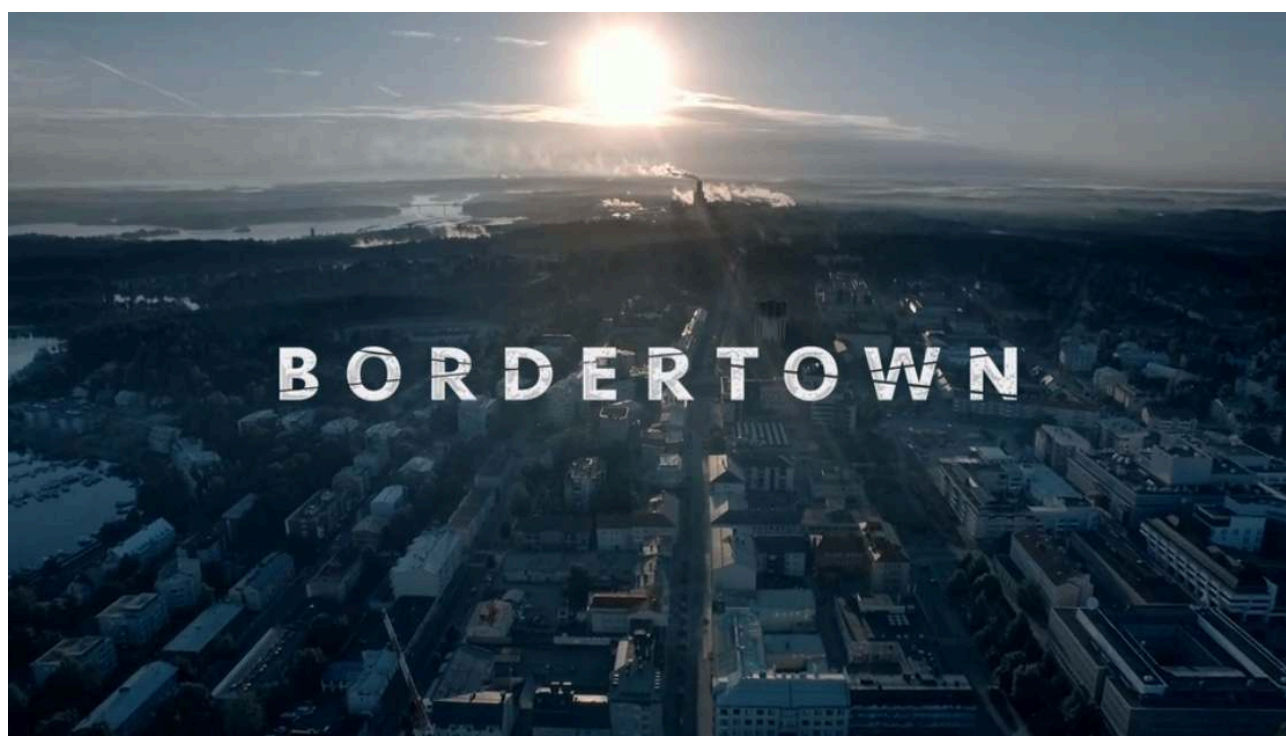

Source: Yle/Bordertown.

The first series centres on the brilliant, but emotionally-stunted detective Kari Sorjonen leaving a prestigious position with the National Bureau of Investigation (Fin. Keskusrikospoliisi) in the capital of Helsinki to dedicate himself to his family. Shortly after joining the Serious Crime Unit (SECRI) in Lappeenranta ${ }^{29}$, he is uncomfortably paired with a new colleague from a neighbouring country, a set-up familiar to regular viewers of Nordic noir crime series in its synthesis of elements from The Killing and The Bridge. However, unlike these Scandinavian series ${ }^{30}$, Bordertown inverts the gender dynamics of the "listening detective" whose socially-awkward "feeling-thinking" engagement with a quiet world of violence ${ }^{31}$ is instrumental to solving each and every murder committed in Lappeenranta ${ }^{32}$. His new partner, Lena, serves as his mirror image in that she operates on an emotional level, using a frothy (Russian) combination of brute force, unfiltered intuition, and devil-may-care approaches to law enforcement to right wrongs. This is in sharp contrast to Sorjonen's (Finnish) affective detachment, rarefied empiricism, and prudish respect for the "rules." ${ }_{33}$

When Jaakkola's daughter goes missing, the two must work together to solve a transborder crime network which lures teen-aged girls into a life of niche prostitution (as referenced in the series opener's title "Doll House/Nukkekoti," young Russians are drugged into a catatonic state and then provided to "European" clients for their sexual pleasure). Eventually, Jaakkola - an FSB agent - is forced out of her job and exiled from her country, finding refuge across the border (though often illicitly returning to Russia). Unmoored in a strange land, she joins forces with her alter ego, Sorjonen, thus instantiating a "permanent liminality" in the series ${ }^{34}$. In the subsequent episodes, the unlikely pair work together to root out drug networks, dog-fighting rings, and other crimes in the bucolic lakeside town where the actual murder rate is close to zero, thus fulsomely undermining the notion of Lappeenranta as "a town of nice crime" and populated by "good people 35 ". This is in keeping with the series' central focus as a family drama first and noir crime show second ${ }^{36}$, an element that Yle promoted via the tagline: "five offenses, two families, one border"37" (viisi rikosta, kaksi perhettä, yksi raja). Rather predictably, Sorjonen's family becomes increasingly embroiled in criminal 
investigations from his wife's (unwitting) involvement in financial impropriety via her old flame (and the town's current mayor), to his daughter's (wrongful) arrest on murder charges in the coda of Series 1 , just as the Jaakkolas consistently serve as a (bodily) site of cross-border criminality from their very first appearance.

The second series begins to delve into Sorjonen's background, establishing his preternatural gifts as the result of psychology therapy during his childhood which taught him to compartmentalise all his memories and social interactions. Herein, the viewer comes to understand why Kari must seal himself off from the outside world and create space-maps of his own recollections in his basement, what he calls "memory palaces." Each such scene begins with him laying down painter's tape on the floor in a mocked-up architectural plan, and then stepping from "room" to "room" to recall key details which are presented as flashbacks, thus adding an extra layer of the liminality in which the series trades. Using the method of loci or mnemonic training ${ }^{38}$, Sorjonen is able to recall exact details of crime scenes, witness testimonies, and various oftenseemingly unimportant ephemera that eventually lead him to incontrovertible conclusions which are always correct. Like the consummate crime-solver Sherlock Homes (to whom Sorjonen is often compared), Kari often sacrifices human engagement at critical moments of sociality to pursue an intellectual quandary to its logical end, therein alienating those closest to him ${ }^{39}$ Not insignificantly, the Finnish Sorjonen also reflects the English Holmes in his Nachträglichkeit (roughly 'afterwardsness'), not only as the singular agent whose sleuthing must be brought to bear, but also as the catalyst for such dark deeds to be committed in the protagonist's proximity, given that the "crime is always constructed after the event which becomes thereby its impossible origin ${ }^{40 "}$. In his failure to "be present" at home or "work" (he has taken leave to care for his spouse whose cancer has relapsed), Kari increasingly manifests as a liminal body as the series progresses, stuck in between the transnational crimes that afflict his adopted home, the dead souls who occupy most of his waking moments, his increasingly estranged family members, and Finnish society at large. He thus becomes literally and physically - a man at the edge, ultimately culminating in he and his family being taken hostage by angry relatives of a victim whose case he had earlier investigated, revealing and resulting in a variety of different interventions across the Finnish-Russian border.

\section{Liminal Landscapes: Screening the "Betwixt and Between" of Lappeenranta}

11 Founded in 1649 and later becoming an important military encampment during the days of the Grand Duchy, Lappeenranta (pop. 73,000) is situated on the shores of Saimaa, Finland's largest lake. Connections to Lake Ladoga in the east and the Gulf of Finland in the south (both via Russia) make the town a key transit zone for tar, wood, pulp, minerals, metals, and other goods (see Image 2). 
Image 2. The Opening Scene of the Series Showing the UPM Kaukas Sawmill from the Edge of Saimaa.

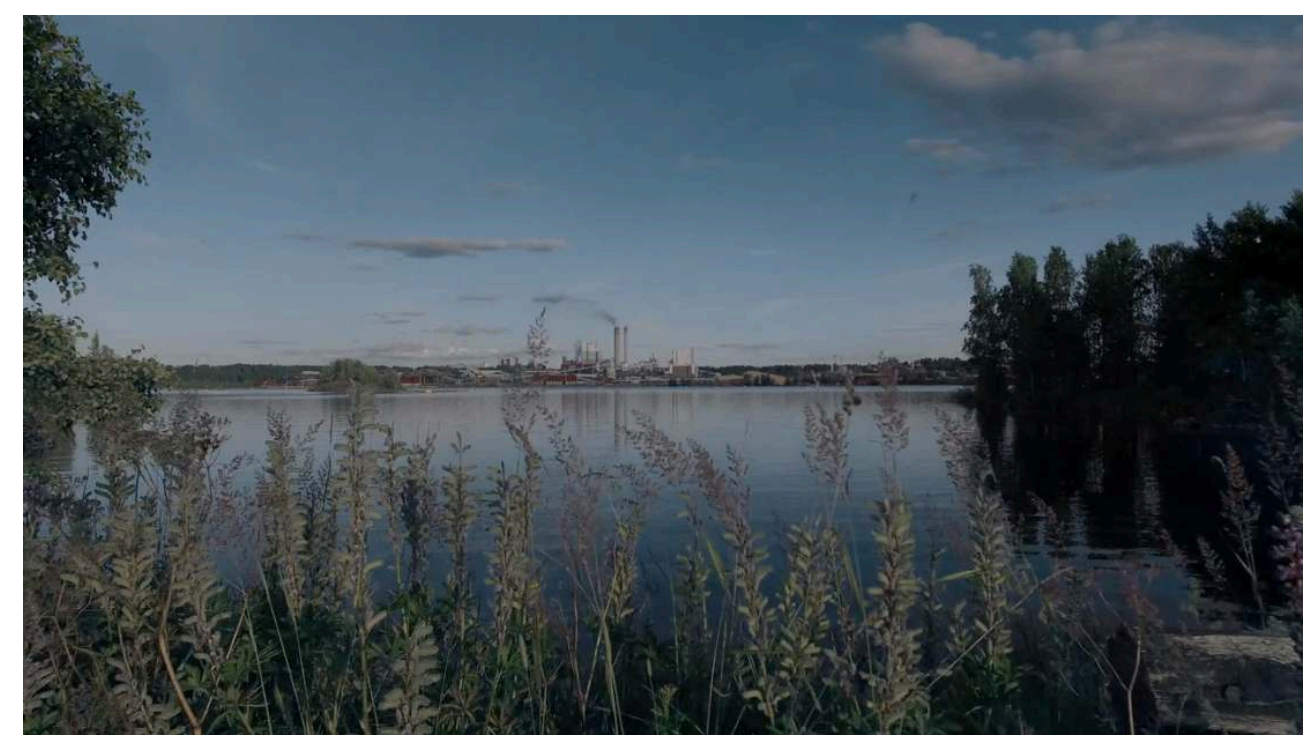

Source: Yle/Bordertown

12 However, the scenic waterfront, ample hotels and cafés, cycling trails, and ready access to nature, including a chance to view the endangered Saimaa Ringed Seal (Pusa hispida saimensis) in the wild, draw in a significant number of tourists every year. ${ }^{41}$ Situated within Karelia, the city is also a destination for Finnish tourists, including many residents of the capital, seeking to explore the culturally-distinct "east" of the country. (There are distinct Karelian dialects (karjalaismurteet) within Finnish, ${ }^{42}$ while Karelian is a distinct language spoken by ethnic Karelians from north-western Russia.) Moreover, Lappeenranta Technological University and a host of "green" technology companies make the city an attractive location for entrepreneurs and corporations seeking to profit from the site's relative proximity to and location in-between Helsinki and Saint Petersburg, i.e. on the edge of both the EU and post-Soviet space. Consequently, Bordertown has a good deal to work with in terms of screening its chosen site of murder and mayhem, despite the smallish size of Lappeenranta.

For the visitor who only knows the city from its televisual representation, finding one's bearings is rather easy, though it is necessary to re-think the city in terms of scope and scale as the cinematography tends to make Lappeenranta seem much bigger than it actually is (one can walk the breadth of it in 45 minutes). Reflecting this inbetweenness of represented/perceived spatiality, one reviewer of the series noted that Bordertown supplies the viewer with "dizzying bird's-eye-view shots that somehow feel simultaneously sweeping and claustrophobic ${ }^{43}$ ". Like the built realms of MalmöCopenhagen (The Bridge), Bergen (Varg Veum), Reykjavik (Stella Blómkvist), and other Nordic noir series, Bordertown relies on a variety of trompe l'œils to make its world "real," an artistic intervention that is quickly understood as one attempts to establish a geographic perspective from the city's effective centre, the shopping mall IsoKristiina (where the Bordertown tour begins). Not insignificantly, the building sits in clear view of a military graveyard ${ }^{44}$ which hosts a statue in memory of those orphans whose parents perished in the defence of the homeland between 1939 and 1945, thus reminding the visitor to the town of Finland's geopolitical precarity (see Image 3). 
Image 3. Memorial to the Orphans of War, Lappeenranta.

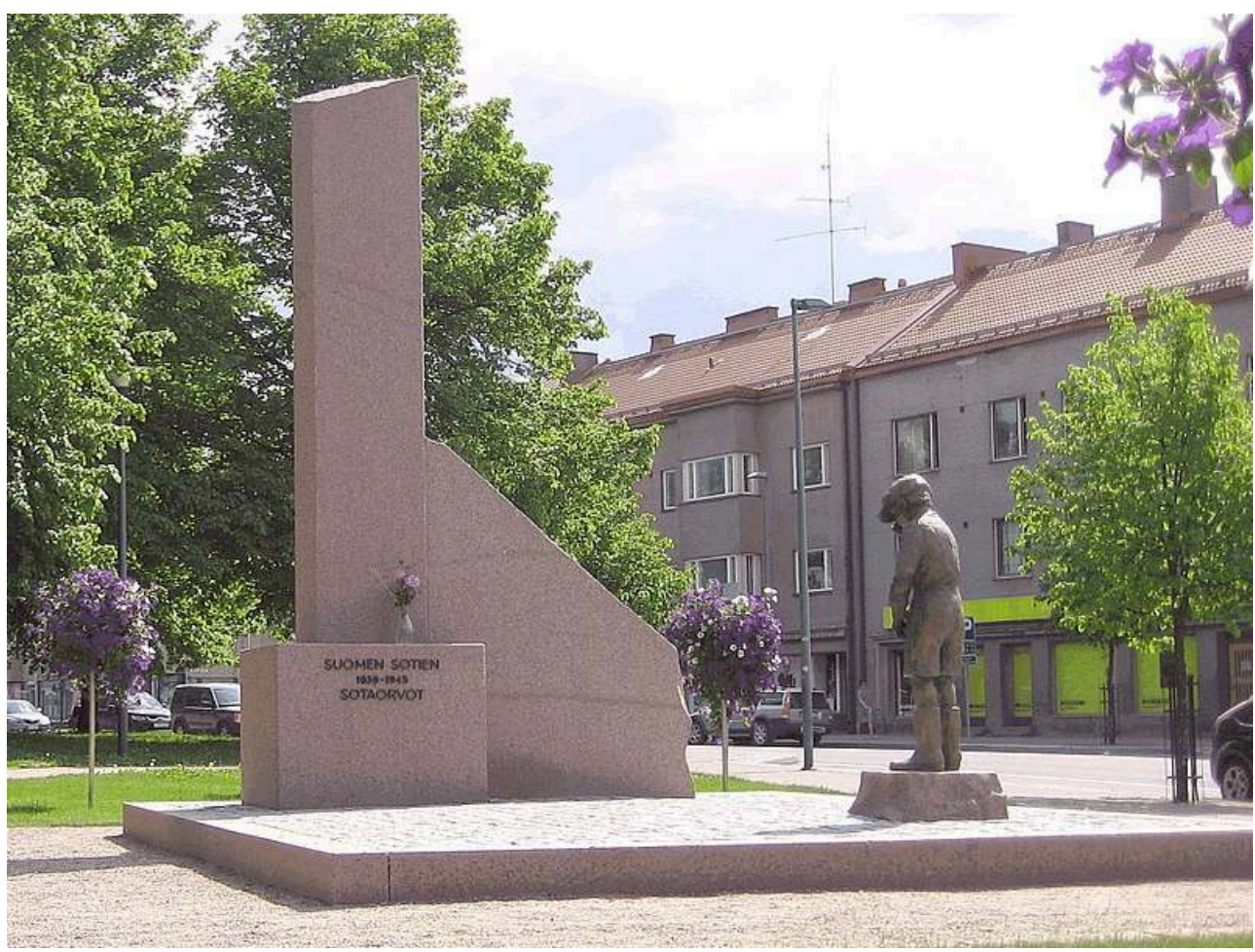

Source: Wikipedia Commons/Jukani Honkanen/GAlexandrovna

Bordertown's creator Miikko Oikkonen wrote the series with Lappeenranta specifically in mind ${ }^{45}$. As a native of the town, Oikkonen came up with idea for the series following a class reunion, aiming to use his deep knowledge of the space to build a world that was so real that it would function as "if it were one of the main characters" of the series ${ }^{46}$. Principal filming took place in the late summer of 2015, while the second season was shot in August and September of 2017. Given the seasonal conditions, Lappeenranta presents as a colourful, bright, and sunny locale, thereby inverting traditional Nordic noir aesthetics which tend to privilege dark spaces, grey places, snowy landscapes, and low-light conditions ${ }^{47}$, thus providing a visual rhetoric that is at odds with the grimness of the subject matter. ${ }^{48}$ That being stated, the showrunners do employ a stark contrast to the bucolic landscapes of the series with the "concrete-dominated environment" of SECRI's headquarters, as well as the bleak cement-walled cellar of the Sorjonen home where Kari builds his memory palaces; according to creators, the purpose of disparity in visual-spatial dynamics is to "place Kari in a simplified environment where there is room for the details, colours, and shapes of the crimes, people, and the outside world ${ }^{49}$.

Expanding on the theme of liminality and landscapes, the first series of Bordertown makes explicit use of water - and more specifically the Lake Saimaa's surface, coastline, and depths - as part of its world-building and diegesis. In film and television, life and death are often linked through the medium of water, and the notion of bodies of water as thresholds between the worlds of the living and the dead is well established in folklore and mythology ${ }^{50}$. However, the ancient Finns believed that, in the beginning, "there was nothing but water and light-an unusual version of the cosmogonic idea ${ }^{51}$ ". As a land of lakes, water is never far away in Finland, and given that the coastline 
serves as a transitional space "where both known and unknown, familiar and unfamiliar, commingle ${ }^{52}$ ", it is not surprising that Bordertown makes use of bodies of water as spaces at the edge of death. Focusing as it does on the differences between murders which are "under the surface" and "above the surface," the series doubles the power of water as a metaphor for liminality. This representation is most profound in the opening scene "The Lady of the Lake: Part 1," which screens a seemingly dead woman in a fish trap at the bottom of Lake Saimaa. However, the viewer soon learns that she is still alive; despite being covered in algae, the chained victim is sustained by access to air tube in macabre underwater prison lingering on the edge of death (see Image 4).

Image 4. The Lady in the Lake between Womb and Tomb.

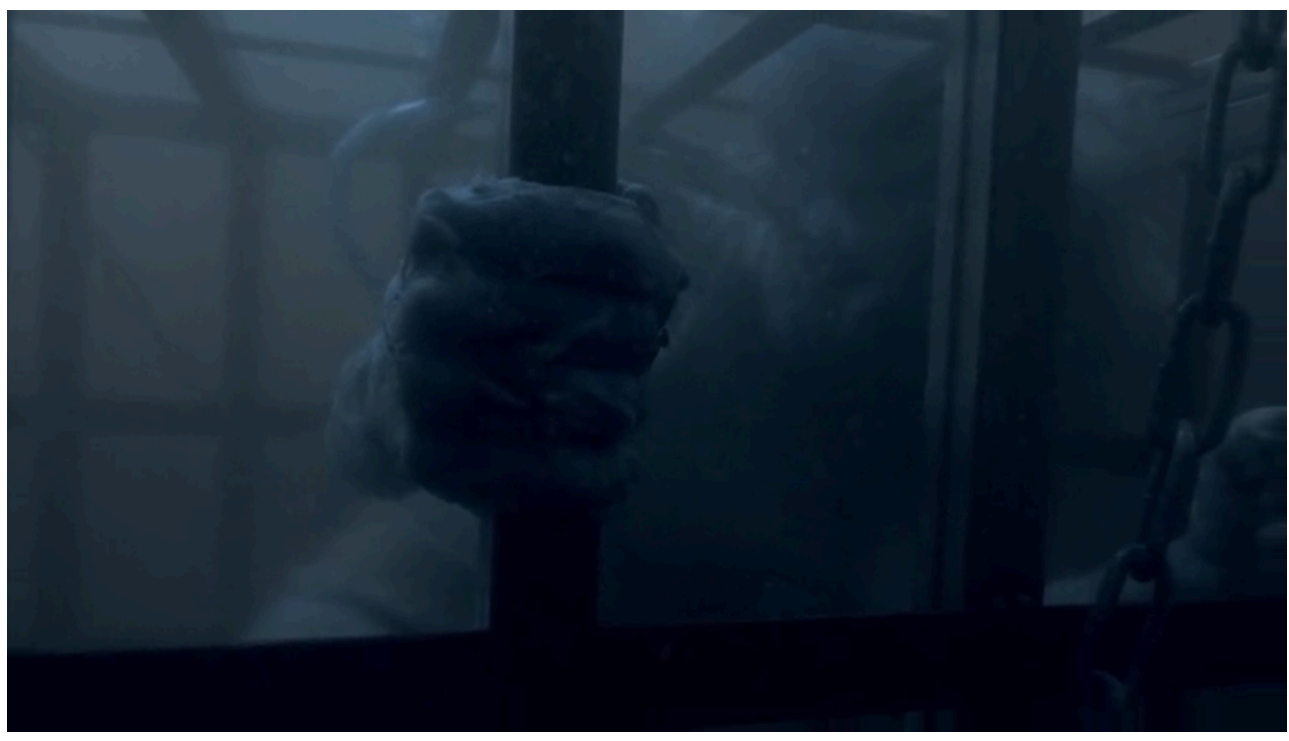

Source: Yle/Bordertown ${ }^{53}$

The series also repeatedly features that most liminal of all entities, a bridge, as an element of its storytelling, deepening the series' embrace of in-betweenness or Lappeenranta as a city on the "edge." As I have argued elsewhere, the televisual bridge - particularly in Nordic noir - functions as a "metonym for (un)regulated flows, personal mobility, conceptual ambiguity, sociocultural interstitiality, and geopolitical (in)security ${ }^{5 "}$ ". Bordertown frequently screens the Luukkaansalmi Bridge, which serves as a signifier of Kari Sorjonen's (futile) desire to separate his work and his private life; however, as any regular viewer of the series knows the "border is not clear" between Sorjonen's "two worlds" of everyday life and the criminal underworld of Lappeenranta ${ }^{55}$. Such movement between worlds at the local level (transitioning from the countryside to the developed areas of Lappeenranta and vice versa) is mirrored and amplified by the regular border-crossings between Finland and Russia, usually involving Sorjonen's partner Lena Jaakkola. Moving beyond the social transversals of Kari's bridge-crossing, Jaakkola's international frontier-crossing "critiques the authority of national borders and the ideology of national identity to which they attest," as well as their "attendant structures of capture and control ${ }^{56 " . ~ T h i s ~ i s ~}$ particularly evident given the laissez-faire attitude that she expresses upon taking refuge in Finland after angering her FSB bosses back in Russia's "northern capital." In its depictions of a screened frontier zone, Bordertown reifies Lulle's assertion that 
"borders select and prioritise social relations," therein determining regimes of exclusion and inclusion based their relationship with the relevant boundary ${ }^{57}$. I now turn to the geopolitics of the embodied tourist experience as one takes the tour of Lappeenranta of Sorjonen's "border town" imaginary.

\section{The Geopolitical Tourist('s) Gaze: Seeing a Border Town/Bordertown through the Prism of Its Imagineers}

17 Building on Gillen and Mostafanezhad's contention that the "tourism encounter is geopolitical," and "invariably constituted through geopolitical discourse and practice ${ }^{58}$, it follows that when a showrunner collaborates with a local tourism board to facilitate Finnish and Russian tourist engagement with a place like Lappeenranta, everyday geopolitics are at play ${ }^{59}$. Following their methodology for unpacking the "place-based, multi-scalar and politically mediated geopolitical experience...coconstituted by residents and tourists ${ }^{60}$, I will now examine the geopolitical tourism encounter produced through the reality-fiction blending of the Bordertown walking tour. Over the past decade, television tourism has become a big business, drawing in viewers of particular series to specific locales they have seen screened in their living rooms. Game of Thrones tours of Dubrovnik, Northern Ireland, and Iceland represent the apogee of this trend ${ }^{61}$; however, Nordic noir series have also prompted a flurry of showspecific tourism options in the southern Scandinavian cities of Ystad (Wallander) and Malmö/Copenhagen ${ }^{62}$ (The Bridge). Like these examples, Sorjonen's Lappeenranta is one on the edge of somewhere else, a place of transition and ambiguity where crime reflects mobility, marginality, and multiplicities of experience and culture.

VisitLappeenranta's Bordertown tour revels in this popular-geopolitical framework; however, the fraught relationship between the Russian Federation and its European neighbours in the wake of the first annexation of territory on the continent since World War II (i.e. the Crimean Peninsula) complicates the dynamics of representation at the EU's eastern frontier. As the tour operators state: "Two worlds meet in the Lappeenranta border region: the fictional crime series Bordertown and the real summer destination ${ }^{63 "}$. Yet, there is more girding this meeting of worlds, namely the unspoken yet always present threat that Russia poses to Finland, and especially the immediate frontier in which Lappeenranta is situated with all its lived realities and temporal modalities associated with its liminal status ${ }^{64}$. The fact that guides must wear a Serious Crime Unit (SECRI) badge while conducting the tour thus turns the city-walk experience into a sort of geopolitical pantomime, with the tour operator assuming the role of a (Finnish) police officer charged with mitigating the effects of (Russian) criminality. Inarguably, this conceit plays differently depending on whether the tour group is composed of domestic (i.e. Finnish) or foreign (i.e. Russian) tourists. Yet in either case, the tourist is being drawn into a popular-geopolitical performance that speaks to the securitisation of the EU's north-eastern periphery: walking around a border town while also walking through the imaginary of Bordertown.

As scholar of geopolitics and a US citizen, my own liminality came into focus as I began to consider how the representation of Lappeenranta's interstitiality presents for these two audiences, just as I reflected on Finland as the epitome of the blurry frontier between "East" and "West" during my youth when Ronald Reagan triggered the "Second Cold War ${ }^{65}$ ". Importantly, concerns about the territorial integrity of Finland 
has re-emerged with former Georgian President Mikheil Saakashvili ${ }^{66}$ penning an inflammatory essay in the influential American journal Foreign Policy suggesting that Vladimir Putin will soon provoke a war with Finland and/or Sweden to shore up his position at home ${ }^{67}$. As Mrozewicz has demonstrated, Finnish cinema has long been engaged with the country's identity vis-à-vis the Russian "Other," with stories that exist in the gap between the "border" and the "boundary" being particularly fecund in terms of sculpting Finnish national identity before and after $1991^{68}$. Building on Mrozewicz's identification in-betweenness that exists between the border and the boundary, I wish to introduce the concept of the edgescape to flag up the ways in which film, television series, and videogames produce realms of understanding about (b)ordered spaces via their visual rhetoric. ${ }^{69}$

20 Elaborating on the notion of edgescape in screened interventions, I argue that Bordertown, alongside other geopolitically-inflected series where national frontiers are central to the narrative arc (Breaking Bad, The Border/Wataha, Pagan Peak/Der Pass, etc.), builds its world in relation to the threshold, with motivations for action flowing outward in multiple directions. This political regime of liminality ${ }^{70}$ often supports the fabula by structuring power relations within a given series, privileging some agents and disenfranchising others (see Image 5).

Image 5. The Securitised Border from the Perspective of the Finnish Side.

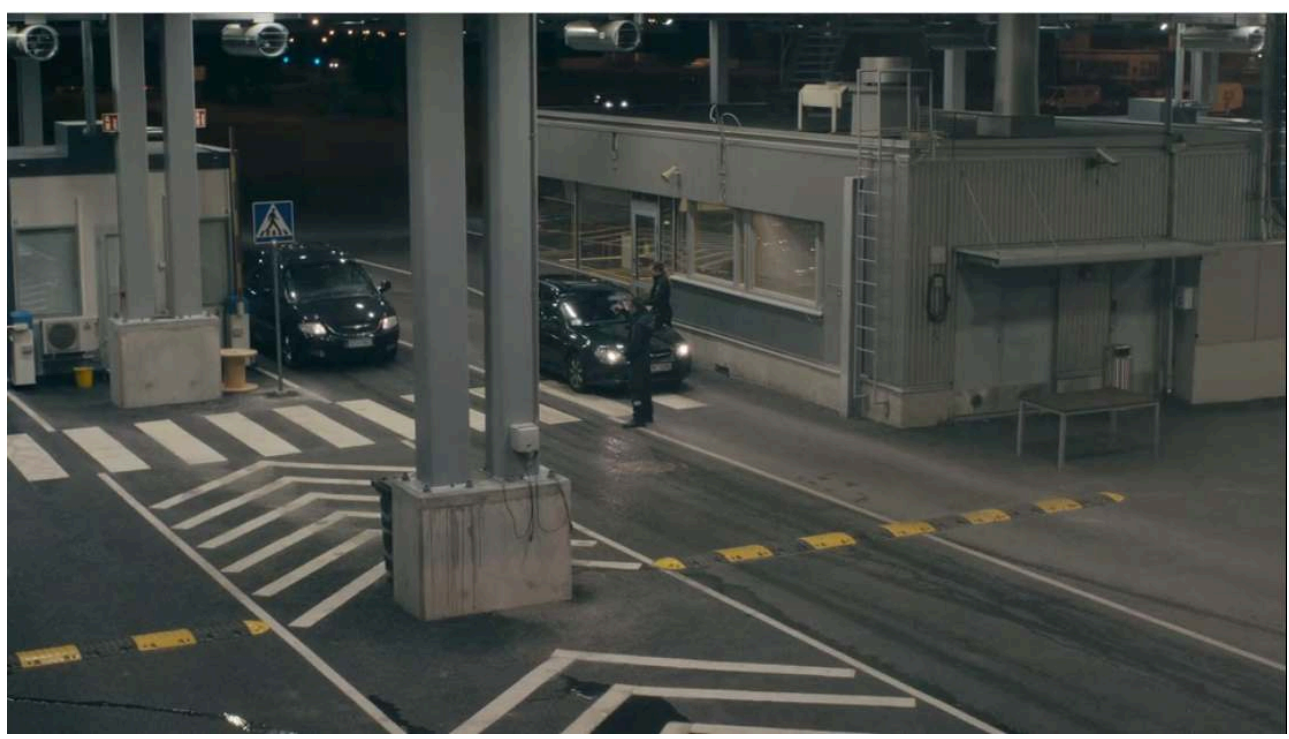

Source: Yle/Bordertown.

21 Hence, certain characters become corporeal sites/sights of state power, with the Jaakkolas serving this function in Bordertown. As female bodies from Russia, living in Finland, and yet "stuck" between these spaces in the interstices of the Karelian borderland, Lena and Katia become canvases upon which Finnish and Russian authorities stake their respective claims (mostly through the actions of male representatives of the state). This line of analysis is not meant to suggest that they lack agency, as both are fiercely autonomous units within Bordertown's narrative arc, but instead to point out that by casting their bodies against the Finnish-Russian frontier, the ruptures of the (re)drawing and enforcing of (b)orders comes to the fore ${ }^{71}$. For the crime-noir tourist, consideration of the female body (or corpse) is an indispensable aspect of the genre ${ }^{72}$, and we know that every time Lena illicitly crosses the border, she 
risks joining that panoply of naked, dead women that populate Scandi-noir's darkened realms of "gendered endangerment ${ }^{73}$ ".

Echoing the focus on the day-to-day banalities of political power in Norden made popular in the hugely-successful Danish drama Borgen, a large part of the tour focusses on the City Council. Reflecting the cooperative relationship between local government and the series, a life-sized cardboard cut-out of the character Kari Sorjonen stands at the entrance to municipal government offices, allowing tourists to take a photograph with Lappeenranta's most famous (albeit fictional) denizen (see image 6).

Image 6. Life-sized Cut Out of Kari Sorjonen in the Lappeenranta City Council Lobby.

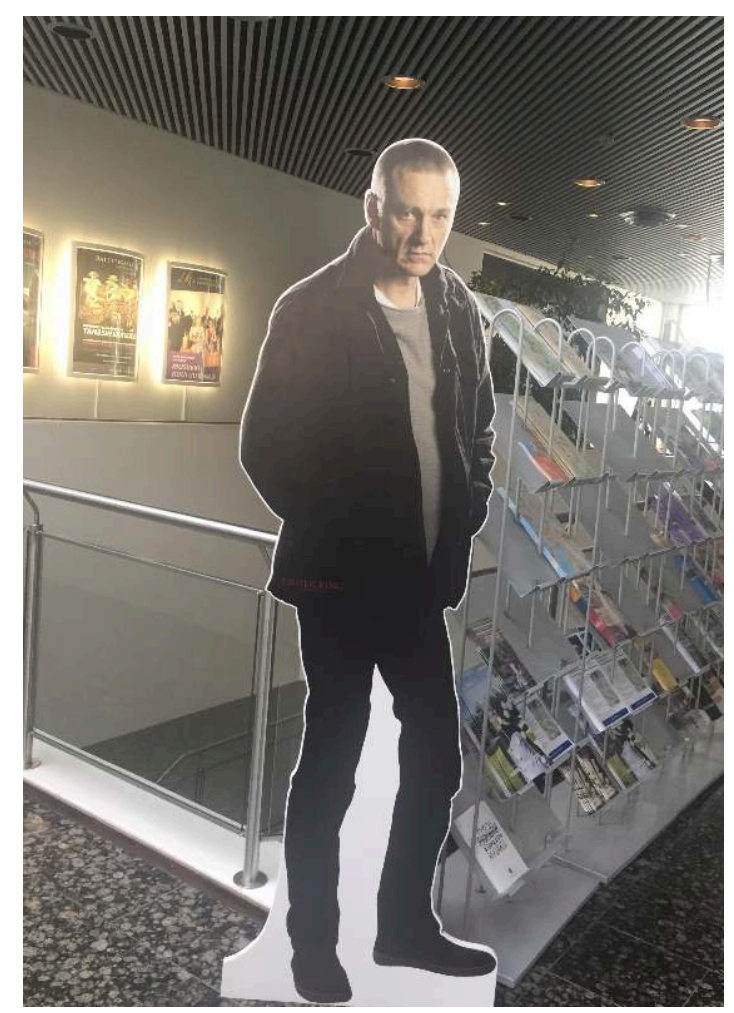

Source: Author's collection.

This is done by contextualising the Town Hall as place of power, both within the landscape of downtown Lappeenranta and as central to the political life of this small city which is increasingly beholden to transborder investment on the part of wealthy Russians. As the script reads: 'Many of the actual Council members actually appear in the scenes that were filmed in the Council Hall. They insisted that they should be allowed to sit in their own places ${ }^{74}$, thus lending a level verisimilitude to the representation. ${ }^{75}$ The first screening of the Council, as the tour reveals, lack genuineness: a totally unnecessary vote on Sorjonen's partner Pauliina (Matleena Kuusniemi) being confirmed as a substitute Council Secretary as the result of a maternity leave. However, the scene makes clear the visible, transparent, and public nature of Finnish government, which is increasingly contrasted with the veiled nature of Russian politics as the series progresses. However, this outwardly open form of governance comes to contrast with the underlying whiff of corruption associated with Mayor Robert Degerman (Janne Virtanen) and his grand plans for a new casino, megahotel, and a renovated airport. As the tour-goer learns: "Degerman refers to Russia as 
an opportunity, not a threat. The grant project of the city administration is also partly based on the belief that the Russian economy will improve in the future and that Lappeenranta will have a lot to offer to tourists, immigrants and businesses coming across the border ${ }^{76 "}$. The narrative - as presented in Series 1 - thus engages with and then premediates the complex economic issues that would result from the Russian Federation's 2014 annexation of Ukrainian territory and the ensuing international sanctions that crashed the rouble, an unintended geopolitical outcome that deeply impacted Lappeenranta with its heavy dependence on economic ties to Saint Petersburg. With Russia's steady rehabilitation within Europe, as well as US President Donald J. Trump's tacit support for President Vladimir Putin's adventurism abroad, Bordertown enmeshes itself with the construction of reality that is dependent upon the resumption of Russian day-trippers to Lappeenranta.

\section{Conclusion - Or Screening the Frontier as a Form of (Popular) Geopolitics}

24 As the call for this special issue makes clear, the narratives that make good television employ sophisticated approaches to political, social, and ideological issues which are often expressed in spatial ways. Series that are able to constitute a genuine sense of space and place are thus in a better position to project complex identities, consequently allowing the viewer to take the story seriously. It is in this conceived/perceived edgescape between the imagined and the real that the built-worlds of cultural producers ${ }^{77}$ meet the lifeworlds of their audiences ${ }^{78}$, therein creating a frisson-inducing melding of the two, and one which necessarily engages political culture ${ }^{79}$. Filmed in and around Lappeenranta, the hometown of its creator, Yle's Bordertown effectively launched Finland as a player in global crime drama production, paving the way for such series as Deadwind/Karppi (Yle, 2018-), Arctic Circle/Ivalo (Yle, 2018-), and All the Sins/ Kaikki synnit (2019-). As I have argued, in its close attention to landscape, place, and space, the series makes a geopolitical intervention in Finland's current delimitation of its difference from but proximity to Russia, a country which looms large in its history as an imperial overseer (1809-1917), wartime adversary (1939-1944), hegemon (1948-1981), and key trading partner. The series both constructs and deconstructs ways of seeing the Finnish Karelia as a borderland, making subtle references to a variety of elements of Finnish history and national identity through its depictions of the region, past events, and points of contestation with the country's powerful eastern neighbour. By introducing the notion of the edgescape to critical television studies via my case study of Bordertown, I have endeavoured to articulate the ways in which small-screen representation engages with geopolitical understandings, while also influencing ways of understanding how the world really works ${ }^{80}$.

I would like to thank Saara Ratilainen for her assistance with the Finnish translations and her insightful comments on the series, as well as Anne Marit Waade for her guidance on interrogating the aesthetics and geopolitics of screened landscapes. I would also like to recognise the generous support of Aarhus University Research Foundation, which funded a portion of my research activities for this essay. Additionally, I wish to express my gratitude to Arto Mäkinen for permission to use images from the series and Rahman Mirka for sharing his expertise on Lappeenranta and Sorjonen, as well as facilitating permission to cite the tourist guide script for 
the official Bordertown tour of the city. Lastly, I want to thank the two blind referees whose comments guided the final revisions of the article.

\section{BIBLIOGRAPHY}

"Finland among the Best in the World", Statistics Finland, 2018, http://www.stat.fi/tup/ satavuotias-suomi/suomi-maailman-karjessa_en.html.

"Sorjonen's Lappeenranta - The Bordertown: Bordertown Filming Locations Tour", VisitLappeenranta, 2017, https://visitlappeenranta.fi/en/Experience/SORJONEN\%E2\%80\%99SLAPPEENRANTA-\%E2\%80\%93-The-Bordertown.

AINAMO-MCDONALD, Maria, "Sorjonen - uusi kotimainen rikossarja (Sorjonen - a new domestic crime series)', Yle, 23 August 2016, https://yle.fi/aihe/artikkeli/2016/08/23/sorjonen-uusikotimainen-rikossarja-alkaa-lokakuussa-ykkosella.

ANDREWS, Hazel, ROBERTS, Les, "Liminality", in International Encyclopedia of the Social \& Behavioral Sciences, ed. James D. Wright, Oxford, Elsevier, 2015, p. 131-137.

APPADURAI, Arjun, Modernity at Large: Cultural Dimensions of Globalization, Minneapolis, University of Minnesota Press, 1996.

AUNESLUOMA, Juhana, “A Nordic Country with East European Problems: British Views on Post-War Finland, 1944-1948", Scandinavian Journal of History Vol. 37, No. 2, 2012, p. 230-245.

AzIZ, Jamaluddin, Transgressing Women: Space and The Body in Contemporary Noir Thrillers, Cambridge, Cambridge Scholars Publishing, 2012.

BEAULIEU, Marie-Claire Anne, The Sea as a Two-Way Passage between Life and Death in Greek Mythology, PhD dissertation, Austin, University of Texas, 2008.

CARTER, Sean, "Geopolitics and the Screen: War, the Body and Violence", Geopolitics Vol. 14, No. 4, 2009, p. 756-763.

COCKER, Emma, "Border Crossing: Practices for Beating the Bounds", in Liminal Landscapes: Travel, Experience and Spaces In-between, ed. Hazel Andrews and Les Roberts, London and New York, Routledge, 2012, p. 50-66.

costlow, Jane, ROSENHOLM, Arja, (eds.), Meanings and Values of Water in Russian Culture, London and New York, Routledge, 2016.

COUlTHARD, Lisa, "The Listening Detective: Thinking Music, Gender, and Transnational Crime's Affective Turn", Television \& New Media Vol. 19, No. 6, 2018, p. 553-568.

DANIELS, Stephen, "Geographical Imagination", Transactions of the Institute of British Geographers Vol. 36, No. 2, 2011, p. 182-187.

DAS, Sukanta, "Introduction", in Border, Globalization and Identity, ed. Sukanta Das, Sanatan Bhowal and Sisodhara Syangbo, Cambridge, Cambridge Scholars Publishing, 2018. 
GILLEN, Jamie, MOSTAFANEZHAB, Mary, “Geopolitical Encounters of Tourism: A Conceptual Approach", Annals of Tourism Research Vol. 75, 2019, p. 70-78.

GREGORY, Derek, Geographical Imaginations, Cambridge, MA, Wiley-Blackwell, 1994.

GUROVA, Olga, RATILAINEN, Saara Maria, "From Shuttle Traders to Middle-Class Consumers: Russian Tourists in Finnish Newspaper Discourse between the Years 1990-2014", Scandinavian Journal of Hospitality and Tourism Vol. 16, No. 1, 2016, p. 51-65.

HABERMAS, Jürgen, Theory of Communicative Action, Volume Two: Lifeworld and System: A Critique of Functionalist Reason, translated by Thomas A. McCarthy, Boston, Beacon Press, 1987 [1981].

HAMMOND, Brady, "The Shoreline in the Sea: Liminal Spaces in the Films of James Cameron", Continuum: Journal of Media \& Cultural Studies Vol. 27, No. 5, 2013, p. 690-703.

HASSLER-FOREST, Dan, Science Fiction, Fantasy, and Politics: Transmedia World-building Beyond Capitalism, Lanham, MD, Rowman \& Littlefield, 2016.

JOENNIEMI, Pertti, “Finland: Always a Borderland?", in Bordering the Baltic: Scandinavian Boundarydrawing Processes, 1900-2000, ed. Madeleine Hurd, Berlin, LIT Verlag, 2010, p. 41-68.

JUKARAINEN, Pirjo, "Norden is Dead - Long Live the Eastwards Faced Euro-North Geopolitical Re-making of Norden in a Nordic Journal”, Cooperation and Conflict Vol. 34, No. 4, 1999, p. 355-382. JUNTUNEN, Tapio, "Helsinki Syndrome: The Parachronistic Renaissance of Finlandization in International Politics”, New Perspectives Vol. 25, No. 1, 2017, p. 55-83.

LAWRENCE, Andy, "Malmö in the Footsteps of The Bridge", Scan Magazine No. 81, 2015, p. 130-131.

LULLE, Aija, "Revitalising Borders: Memory, Mobility and Materiality in a Latvian-Russian Border Region”, Culture Unbound: Journal of Current Cultural Research Vol. 8, No. 1, 2016, p. 43-61.

LUNDBERG, Christine, ZIAKAS, Vassilios, MORGAN, Nigel, “Conceptualising On-Screen Tourism Destination Development”, Tourist Studies Vol. 18, No. 1, 2018, p. 83-104.

MÄLKSOO, Maria, "Liminality and the Politics of the Transitional", in Handbook of Political Anthropology, ed. Harald Wydra and Bjorn Thomassen, Cheltenham, Edward Elgar, 2018, p. 145-159.

MARTIN, Niall, Iain Sinclair: Noise, Neoliberalism and the Matter of London, New York, Bloomsbury Publishing, 2015.

MCCULLOUGH, J. A., "Light and Darkness”, in Encyclopcedia of Religion and Ethics: Life and Death, ed. James Hastings, John Alexander Selbie and Louis Herbert Gray, Edinburgh, T. \& T. Clark, 1916, p. 47-63.

MIRKA, Rahman, OIKKONEN, Miikko, "Official Tour of the Shooting Locations of the Bordertown TV Series” (written document), 2018.

MOSTAFANEZHAD, Mary, NORUM, Roger, "Towards a Geopolitics of Tourism”, Annals of Tourism Research Vol. 61, 2016, p. 226-228.

MROZEWICZ, Anna Estera, Beyond Eastern Noir: Reimaging Russia and Eastern Europe in Nordic Cinemas, Edinburgh, Edinburgh University Press, 2018.

PAASI, Anssi, "Boundaries as Social Practice and Discourse: The Finnish-Russian Border", Regional Studies Vol. 33, No. 7, 1999, p. 669-680. 
RAITASALO, Jyri, “Scandinavia Won't Be Russia's Next Target”, Foreign Policy, March $27^{\text {th }}, 2019$, https://foreignpolicy.com/2019/03/27/scandinavia-wont-be-russias-next-target-putin-natofinland-sweden-defense-saakashvili-georgia/.

REDVALL, Eva, JENSEN, Pia Majbritt, WAADE, Anne Marit, (eds.), Danish Television Drama: Global Lessons from a Small Nation, Gothenburg, Nordicom, 2020.

RODERICK, Hilda, DAVIDSON, Ellis, Myths and Symbols in Pagan Europe: Early Scandinavian and Celtic Religions, Syracuse, Syracuse University Press, 1988.

SAAKASHVILI, Mikheil, "Russia's Next Land Grab Won't Be in an Ex-Soviet State. It Will Be in Europe”, Foreign Policy, March 15 ${ }^{\text {th }}, 2019$, https://foreignpolicy.com/2019/03/15/russias-nextland-grab-wont-be-in-an-ex-soviet-state-it-will-be-in-europe-putin-saakashvili-sweden-finlandarctic-northern-sea-route-baltics-nato/.

SAUNDERS, Robert A., "The Geopolitics of Russophonia: The Problems and Prospects of PostSoviet 'Global Russian'”, Globality Studies Journal No. 40, 2014, p. 1-22.

SAUNDERS, Robert A., "A Dark Imaginarium: The Bridge, Malmö, and the Making of a 'NonExistent' Place”, Journal of Urban Cultural Studies Vol. 4, No. 3, 2017a, p. 361-385.

SAUNDERS, Robert A., Popular Geopolitics and Nation Branding in the Post-Soviet Realm, London and New York, Routledge, 2017b.

SAUNDERS, Robert A., "Geopolitical Television at the (B)order: Liminality, Global Politics, and World-Building in The Bridge", Social \& Cultural Geography Vol. 20, No. 7, 2019a, p. 981-1003.

SAUNDERS, Robert A., "Small Screen IR: A Tentative Typology of Geopolitical Television”, Geopolitics Vol. 24, No. 3, 2019b, p. 691-727.

SHIM, David, "Between the International and the Everyday: Geopolitics and Imaginaries of Home”, International Studies Review Vol. 18, No. 4, 2016, p. 597-613.

SHIRER, William R., KONRAD, Boris N., MULLER, Nils C. J., WAGNER, Isabella, FERNANDEZ, Guillén, CZISCH, Michael, GREICIUS, Michael D., DRESLER, Martin, "Mnemonic Training Reshapes Brain Networks to Support Superior Memory”, Neuron Vol. 93, No. 5, 2017, p. 1227-1235.

SIGANPORIA, Harmony, KARIORIS, Frank G., "Rupture and Exile: Permanent Liminality in Spaces for Movement and Abandonment", Culture Unbound Vol. 8, 2016, p. 20-25.

SMETHURST, Paul, “The Geocritical Imagination”, English Language Notes Vol. 52, No. 1, 2014, p. 175-186.

STUDARUS, Laura, "How the Finnish Survive without Small Talk", BBC, November $16^{\text {th }}, 2018$, http://www.bbc.com/travel/story/20181016-how-the-finnish-survive-without-small-talk.

THOMASSEN, Bjørn, Liminality and the Modern: Living through the In-between, Farnham and Burlington, VT Ashgate, 2014.

TISCHLEDER, Babette B., "Thickening Seriality: A Chronotopic View of World Building in Contemporary Television Narrative", Velvet Light Trap: A Critical Journal of Film \& Television No. 79, 2017, p. 120-125.

TOFT HANSEN, Kim, WAADE, Anne Marit, Locating Nordic Noir: From Beck to The Bridge, Basingstoke, Palgrave Macmillan, 2017.

VAN GENNEP, Arnold, The Rites of Passage, Chicago, University of Chicago Press, 1960 [1909].

VLOYANTES, John P., Silk Glove Hegemony: Finnish-Soviet Relations, 1944-1974: A Case Study of the Theory of the Soft Sphere of Influence, Kent, Kent State University Press, 1975. 
WAADE, Anne Marit, "Nordic Noir Tourism and Television Landscapes: In the Footsteps of Kurt Wallander and Saga Norén”, Scandinavica Vol. 55, No. 1, 2016, p. 41-65.

WELDES, Jutta, ROWLEY, Christina, “So, How Does Popular Culture Relate to World Politics?” In Popular Culture and World Politics: Theories, Methods, Pedagogies, ed. Federica Caso and Caitlin Hamilton, Bristol, E-International Relations, 2015.

wHARTON, David, “Netflix’s ‘Bordertown' Blends Crime and Family Drama into a Stylish, Satisfying Whole”, Daily Dot, 6 April 2017, https://www.dailydot.com/upstream/bordertownnetflix-review/.

WOLF, Mark J. P., Building Imaginary Worlds: The Theory and History of Subcreation, New York and London, Routledge, 2012.

\section{NOTES}

1. For a period of time, Finland was the only EU country to share a border with the Russian Federation, giving it a singular position within the trade bloc. See Anssi Paasi, "Boundaries as Social Practice and Discourse: The Finnish-Russian Border", Regional Studies Vol. 33, No. 7, 1999, p. 669-680.

2. Sean Carter, "Geopolitics and the Screen: War, the Body and Violence", Geopolitics Vol. 14, No. 4, 2009, p. 756-763; Robert A. Saunders, Popular Geopolitics and Nation Branding in the Post-Soviet Realm, London and New York, Routledge, 2017b; Anna Estera Mrozewicz, Beyond Eastern Noir: Reimaging Russia and Eastern Europe in Nordic Cinemas, Edinburgh, Edinburgh University Press, 2018.

3. Robert A. Saunders, "Small Screen IR: A Tentative Typology of Geopolitical Television", Geopolitics Vol. 24, No. 3, 2019b, p. 691-727.

4. Robert A. Saunders, "A Dark Imaginarium: The Bridge, Malmö, and the Making of a 'NonExistent' Place", Journal of Urban Cultural Studies Vol. 4, No. 3, 2017a, p. 361-385.

5. Kim Toft Hansen and Anne Marit Waade, Locating Nordic Noir: From Beck to The Bridge, Basingstoke, UK, Palgrave Macmillan, 2017.

6. Paasi, p. 670.

7. Mary Mostafanezhad and Roger Norum, "Towards a Geopolitics of Tourism", Annals of Tourism Research Vol. 61, 2016, p. 226.

8. Sukanta Das, "Introduction", in Border, Globalization and Identity, ed. Sukanta Das, Sanatan Bhowal and Sisodhara Syangbo, Cambridge, Cambridge Scholars Publishing, 2018, p. 1-11.

9. See Mark J. P. Wolf, Building Imaginary Worlds: The Theory and History of Subcreation, New York and London, Routledge, 2012.

10. I took an individual excursion on 18 June 2018. My guide informed me that I was the first guest to request an English-language tour as all previously conducted tours had either been in Finnish or Russian.

11. Jamie Gillen and Mary Mostafanezhad, "Geopolitical Encounters of Tourism: A Conceptual Approach", Annals of Tourism Research Vol. 75, 2019, p. 70-78.

12. Derek Gregory, Geographical Imaginations, Cambridge, MA, Wiley-Blackwell, 1994; Stephen Daniels, "Geographical Imagination", Transactions of the Institute of British Geographers Vol. 36, No. 2, 2011, p. 182-187; Paul Smethurst, "The Geocritical Imagination”, English Language Notes Vol. 52, No. 1, 2014, p. 175-186.

13. Arnold van Gennep, The Rites of Passage, Chicago, University of Chicago Press, 1960 [1909]; Bjørn Thomassen, Liminality and the Modern: Living through the In-between, Farnham and Burlington, Ashgate, 2014; Hazel Andrews and Les Roberts, "Liminality", in International 
Encyclopedia of the Social \& Behavioral Sciences, ed. James D. Wright, Oxford, Elsevier, 2015, p. 131-137.

14. Saunders, 2017b, p. 1.

15. Paasi, art. cit.

16. Pertti Joenniemi, "Finland: Always a Borderland?", in Bordering the Baltic: Scandinavian Boundary-drawing Processes, 1900-2000, ed. Madeleine Hurd, Berlin, LIT Verlag, 2010, p. 41.

17. Finns speak a language within the Baltic-Finnic subgroup of the Uralic language family, being most closely related to Estonian, but also tied to a number of less-spoken tongues native to north-eastern Russia. Distant links to Hungarian, Sami, and the indigenous languages of northern Siberia also exist.

18. Pirjo Jukarainen, "Norden is Dead - Long Live the Eastwards Faced Euro-North Geopolitical Re-making of Norden in a Nordic Journal", Cooperation and Conflict Vol. 34, No. 4, 1999, p. 355-382.

19. Paasi, p. 671.

20. Juhana Aunesluoma, "A Nordic Country with East European Problems: British Views on PostWar Finland, 1944-1948", Scandinavian Journal of History Vol. 37, No. 2, 2012, p. 230-245.

21. Tapio Juntunen, "Helsinki Syndrome: The Parachronistic Renaissance of Finlandization in International Politics", New Perspectives Vol. 25, No. 1, 2017, p. 55-83.

22. John P. Vloyantes, Silk Glove Hegemony: Finnish-Soviet Relations, 1944-1974: A Case Study of the Theory of the Soft Sphere of Influence, Kent, Ohio, Kent State University Press, 1975. Unlike the Soviet "satellite" states within the Warsaw Treaty Organisation, Helsinki maintained full control over its internal policies, including a market economy-cum-welfare state that mirrored developments in the west (i.e. Scandinavia).

23. This position stands in contrast to Sweden, which came to see itself under a de facto-if-not-de jure NATO security umbrella during the Cold War (an orientation that Finland similarly adopted since the dissolution of the USSR in late 1991 yoking its status to its western neighbour and former imperial overlord).

24. Finland occupies about 0.07 per cent of the world's area with a similar percentage in terms of population.

25. Admittedly, Swedish-speakers represent a significant portion of the population (5.2\%); however, they are a well-integrated community, and one which enjoys substantive rights associated with the language and identity.

26. "Finland among the Best in the World", Statistics Finland, December $5^{\text {th }}, 2018$, http:// www.stat.fi/tup/satavuotias-suomi/suomi-maailman-karjessa_en.html, consulted May $23^{\text {rd }}, 2020$. 27. This refers not only incoming Russian tourists, but also outgoing EU citizens. Lappeenranta is one of the few places in the union where tourists can enter the Russian Federation without a visa, due to daily boat tours to Vyborg (the Finnish capital Helsinki is another).

28. Robert A. Saunders, "The Geopolitics of Russophonia: The Problems and Prospects of PostSoviet “Global Russian"', Globality Studies Journal No. 40, 2014, p. 1-22.

29. A figment of the series, SECRI is a special, limited-term project that works directly with Europol, focussed on preventing and investigating serious crime in the Finnish-Russian border region.

30. Despite often being conflated with "Scandinavia" in everyday (Anglophone) geographic understanding, Finland is distinct due to its aforementioned ethno-linguistic constitution and predominantly mainland location. However, the country is firmly situated within the geopolitical continuum of Nordic Europe (or Norden as it is known within the region), thus forming the eastern fringe of a group of states that includes Sweden, Denmark, Norway, and Iceland.

31. Lisa Coulthard, "The Listening Detective: Thinking Music, Gender, and Transnational Crime's Affective Turn", Television \& New Media Vol. 19, No. 6, 2018, p. 553-568.

32. Once again, Bordertown departs from the classic Nordic noir modus in that each series consists of multiple meta-crimes, with each solved over two or three episodes, thus establishing a liminal 
space between the American one-and-done CSI: Crime Scene Investigation model and the seasonlength unravelling of a crime spree that defines the previously-referenced series from northern Europe.

33. This gendered dynamic stands in contrast to The Bridge, where an emotional, rule-breaking (male) Dane is paired with a Swedish (female) officer who slavishly follows protocol and lacks empathy; yet, there are strong similarities with the detective pairing of a quiet and careful Swedish-Sami man with a French-Berber woman who plays it fast-and-loose in Midnight Sun.

34. Harmony Siganporia and Frank G. Karioris, "Rupture and Exile: Permanent Liminality in Spaces for Movement and Abandonment", Culture Unbound, Vol. 8, 2016, p. 20-25.

35. Rahman Mirka and Miikko Oikkonen, "Official Tour of the Shooting Locations of the Bordertown TV Series", 2018.

36. David Wharton, “Netflix's 'Bordertown' Blends Crime and Family Drama into a Stylish, Satisfying Whole", Daily Dot, 6 April 2017, https://www.dailydot.com/upstream/bordertownnetflix-review/, consulted May $23^{\text {rd }}, 2020$.

37. Maria Ainamo-McDonald, "Sorjonen - uusi kotimainen rikossarja (Sorjonen - a new domestic crime series)”, Yle, 23 Aug. 2016, https://yle.fi/aihe/artikkeli/2016/08/23/sorjonen-uusikotimainen-rikossarja-alkaa-lokakuussa-ykkosella, consulted May $23^{\text {rd }}, 2020$.

38. William R. Shirer, Boris N. Konrad, Nils C. J. Muller, Isabella Wagner, Guillén Fernández, Michael Czisch, Michael D. Greicius, and Martin Dresler, "Mnemonic Training Reshapes Brain Networks to Support Superior Memory", Neuron Vol. 93, No. 5, 2017, p. 1227-1235.

39. Contra the standard analysis of Sorjonen as a Nordic replica of the world's most famous detective, Kari tends towards silence, especially when in deep thought. While Holmes and many of the male detectives in crime dramas talk through their investigations, Sorjonen more resembles the (feminine) "listening detective" rather than the (masculine) "sonic forensic scientist" (Lisa Coulthard, "The Listening Detective: Thinking Music, Gender, and Transnational Crime's Affective Turn", Television \& New Media Vol. 19, No. 6, 2018, p. 553-568). That being stated, "sitting in silence" is a national trait of the Finns (Laura Studarus, "How the Finnish Survive without Small Talk", BBC, 16 Nov. 2018, http://www.bbc.com/travel/story/20181016-how-thefinnish-survive-without-small-talk, consulted May $23^{\text {rd }}, 2020$ ), and thus represents an explicit way to distinguish Kari from his partner Lena in the series.

40. Niall Martin, Iain Sinclair: Noise, Neoliberalism and the Matter of London, New York, Bloomsbury Publishing, 2015, p. 17.

41. According to VisitLappeenranta, 1.7 million tourists came to the city and the wider South Karelia region in 2017 (the second-most popular destination after Helsinki-Uusimaa Region), https://visitlappeenranta.fi/en, consulted May $23^{\text {rd }}, 2020$; the vast majority of these visitors are Russians coming to the area for shopping trips (see Olga Gurova and Saara Maria Ratilainen, "From Shuttle Traders to Middle-Class Consumers: Russian Tourists in Finnish Newspaper Discourse between the Years 1990-2014", Scandinavian Journal of Hospitality and Tourism Vol. 16, No. 1, 2016, p. 51-65.

42. Many of the actors in Bordertown attempt to affect some sort of Karelian provenance in their spoken Finnish; however, the Lappeenranta locals have been rather vocal about the failure of these attempts at linguistic authenticity (Mirka and Oikkonen, op. cit.).

43. David Wharton, art. cit.

44. The cemetery features in Series 1 when an explosion at Original Sokos Hotel Lappee (which faces the Town Hall) sends body parts flying across the parking lot, coming to rest atop the graves.

45. "Sorjonen's Lappeenranta - The Bordertown: Bordertown Filming Locations Tour", VisitLappeenranta, 2017, https://visitlappeenranta.fi/en/Experience/SORJONEN\%E2\%80\%99SLAPPEENRANTA-\%E2\%80\%93-The-Bordertown, consulted May $23^{\text {rd }}, 2020$.

46. Mirka and Oikkonen, op. cit. 
47. Toft Hansen and Waade, op. cit.

48. In doing so, Bordertown follows Wallander and the Swedish-French series Midnight Sun in establishing a new sub-genre of Nordic noir that is bathed in light of the world, just as it revels in darkness of Man.

49. Mirka and Oikkonen, op. cit.

50. Hilda Roderick, and Ellis Davidson, Myths and Symbols in Pagan Europe: Early Scandinavian and Celtic Religions, Syracuse, Syracuse University Press, 1988; Jane Coslow, and Arja Rosenholm (eds.), Meanings and Values of Water in Russian Culture, London and New York, Routledge, 2016; MarieClaire Anne Beaulieu, The Sea as a Two-Way Passage between Life and Death in Greek Mythology, PhD dissertation, Austin, University of Texas, 2008.

51. J. A. McCullough, "Light and Darkness", in Encyclopcedia of Religion and Ethics: Life and Death, ed. James Hastings, John Alexander Selbie and Louis Herbert Gray, Edinburgh, T. \& T. Clark, 1916, p. 48.

52. Brady Hammond, "The Shoreline in the Sea: Liminal Spaces in the Films of James Cameron", Continuum: Journal of Media \& Cultural Studies Vol. 27, No. 5, 2013, p. 693.

53. As the tour points out, the first murder investigation in the series begins with a drowned body in Lake Saimaa, in the second case, Sorjonen's daughter almost drowns in a spa pool, the "Woman in the Lake" finds a parallel via a murder in the Neva River in neighbouring Russia, and the final case of the first series begins on a sailboat in the middle of Lake Saimaa (Mirka and Oikkonen, op. cit.).

54. Robert A. Saunders, "Geopolitical Television at the (B)order: Liminality, Global Politics, and World-Building in The Bridge", Social \& Cultural Geography Vol. 20, No. 7, 2019a, p. 988.

55. Mirka and Oikkonen, op. cit.

56. Emma Cocker, "Border Crossing: Practices for Beating the Bounds", in Liminal Landscapes: Travel, Experience and Spaces In-between, ed. Hazel Andrews and Les Roberts, London and New York, Routledge, 2012, p. 55.

57. Aija Lulle, "Revitalising Borders: Memory, Mobility and Materiality in a Latvian-Russian Border Region", Culture Unbound: Journal of Current Cultural Research Vol. 8, No. 1, 2016, p. 48.

58. Gillen and Mostafanezhad, p. 70.

59. David Shim, "Between the International and the Everyday: Geopolitics and Imaginaries of Home", International Studies Review Vol. 18, No. 4, 2016, p. 597-613.

60. Gillen and Mostafanezhad, p. 70.

61. Christine Lundberg, Vassilios Ziakas, and Nigel Morgan, "Conceptualising On-Screen Tourism Destination Development”, Tourist Studies Vol. 18, No. 1, 2018, p. 83-104.

62. Andy Lawrence, "Malmö in the Footsteps of The Bridge", Scan Magazine No. 81, 2015, p. 130-131; Anne Marit Waade, "Nordic Noir Tourism and Television Landscapes: In the Footsteps of Kurt Wallander and Saga Norén”, Scandinavica Vol. 55, No. 1, 2016, p. 41-65; Robert Saunders, 2017a, art. cit.

63. Mirka and Oikkonen, op. cit.

64. Lulle, art. cit.

65. Aunesluoma, art. cit.

66. Mikheil Saakashvili, "Russia's Next Land Grab Won't Be in an Ex-Soviet State. It Will Be in Europe", Foreign Policy, March 15 ${ }^{\text {th }}, 2019$, https://foreignpolicy.com/2019/03/15/russias-nextland-grab-wont-be-in-an-ex-soviet-state-it-will-be-in-europe-putin-saakashvili-sweden-finlandarctic-northern-sea-route-baltics-nato/, consulted May $23^{\text {rd }}, 2020$.

67. Neither of these Nordic countries are parties to NATO; however, the pact's military doctrine has long been interpreted in such a way that a Soviet/Russian invasion of either state would be treated as an action so provocative that it would trigger a response akin to the invasion of a member-state; however, US President Donald Trump's open dismissal of NATO as an obsolete entity has recently put this assumption into question. Regardless, Finland represents the EU 
country most able to defend its territorial integrity by effectively eschewing the post-Cold War "peace dividend" that characterised most European states' downgraded defence spending. See Jyri Raitasalo, “Scandinavia Won't Be Russia's Next Target”, Foreign Policy, March $27^{\text {th }}, 2019$, https://foreignpolicy.com/2019/03/27/scandinavia-wont-be-russias-next-target-putin-natofinland-sweden-defense-saakashvili-georgia/, consulted May $23^{\text {rd }}, 2020$.

68. Anna Estera Mrozewicz, Beyond Eastern Noir: Reimaging Russia and Eastern Europe in Nordic Cinemas, Edinburgh, Edinburgh University Press, 2018, p. 72.

69. I draw inspiration here from Arjun Appadurai (Modernity at Large: Cultural Dimensions of Globalization, Minneapolis, University of Minnesota Press, 1996), aiming to push his concept of the mediascape somewhat further in terms of the application of other "scapes" which are intermeshed in multivalent and evolving forms of modernity. As I have explored elsewhere (Saunders, 2019a, art. cit.), The Bridge and its adaptations exemplify the intertwining of border zones through characters, events, sites, and flows.

70. Maria Mälksoo, "Liminality and the Politics of the Transitional", in Handbook of Political Anthropology, ed. Harald Wydra and Bjorn Thomassen, Cheltenham, Edward Elgar Publishing, 2018, p. 145-159.

71. Lulle, art. cit.

72. Jamaluddin Aziz, Transgressing Women: Space and The Body in Contemporary Noir Thrillers, Cambridge, Cambridge Scholars Publishing, 2012.

73. Coulthard, p. 555.

74. Mirka and Oikkonen, op. cit.

75. Interestingly, my tour guide Rahman Mirka appeared as the Chairman of the City Board in an episode of the series, thus linking representation, reality, and tourism.

76. Mirka and Oikkonen, op. cit.

77. Wolf, op. cit; Babette B. Tischleder, "Thickening Seriality: A Chronotopic View of World Building in Contemporary Television Narrative", Velvet Light Trap: A Critical Journal of Film \& Television No. 79, 2017, p. 120-125.

78. Jürgen Habermas, Theory of Communicative Action, Volume Two: Lifeworld and System: A Critique of Functionalist Reason, translated by Thomas A. McCarthy, Boston, Beacon Press, 1987 [1981]; Eva Redvall, Pia Majbritt Jensen, and Anne Marit Waade (eds.), Danish Television Drama: Global Lessons from a Small Nation, Gothenburg, Nordicom, 2020.

79. Dan Hassler-Forest, Science Fiction, Fantasy, and Politics: Transmedia World-building Beyond Capitalism, Lanham, MD, Rowman \& Littlefield, 2016.

80. Jutta Weldes and Christina Rowley, "So, How Does Popular Culture Relate to World Politics?" in Popular Culture and World Politics: Theories, Methods, Pedagogies, ed. Federica Caso and Caitlin Hamilton, Bristol, E-International Relations Publishing, 2015, p. 11-34.

\section{ABSTRACTS}

Finnish programming is increasingly finding success beyond the country's borders. Sorjonen - or as it is known internationally, Bordertown - is perhaps the best example of this trend, having been distributed with subtitles in multiple languages via Netflix. Set in the idyllic lakeside resort of Lappeenranta, which is also Finland's closest city to St. Petersburg, Russia, Bordertown revolves around Detective Inspector Kari Sorjonen (Ville Virtanen) following his relocation there in the 
wake of his wife's illness. Hoping to leave major crimes behind in the capital of Helsinki, Sorjonen is soon investigating horrific violence and gruesome events. The criminal networks he discovers often extend far beyond tiny Lappeenranta, thus placing the city at the nexus of illicit flows that link Russia to continental Europe. While Bordertown does not engage in the crass Russophobia of many other screened geopolitical interventions, the series does deploy its setting's geopolitical liminality to engage with a variety of challenges to Europe. This essay interrogates Bordertown's use of a real place, i.e. Lappeenranta, to sculpt a geopolitical imaginary that can tell a story. Focussing on a variety of elements from water to windmills and from the city council to the cellar, I employ various scales of engagement (i.e. the local, border, state, land and nation) to examine the series' narrative, dramaturgical and visual "scaping" of a chimerical "border town" that maps on to the "real" city of Lappeenranta. Informed by my June 2018 Bordertown TV-Series Walking Tour, my analysis synthesises approaches from cultural geography, critical IR and television studies to assess the Bordertown's intervention in the everyday, lived and embodied geopolitics of this south-eastern Finnish city.

Les séries finlandaises rencontrent un succès grandissant à l'étranger. Sorjonen - rebaptisée Bordertown pour le marché international - est sans doute la meilleure illustration de cette tendance récente car elle bénéficie d'une diffusion sous-titrée en plusieurs langues sur Netflix. Bordertown relate l'arrivée de l'inspecteur Kari Sorjonen (Ville Virtanen) dans la ville de Lappeenranta, sur les rives du lac Saimaa à proximité de la frontière russe, suite au cancer de sa femme. Sorjonen abandonne rapidement ses espoirs de vie provinciale calme lorsqu'il est confronté à des affaires aussi violentes que sordides. Les réseaux criminels qu'il révèle débordent les frontières de sa petite ville, plaçant cette dernière au centre de trafics illicites liant la Russie à l'Europe continentale. Si Bordertown évite la russophobie grossière que trahissent d'autres séries à tonalité géopolitique, elle exploite néanmoins sa liminalité géographique pour aborder des problèmes européens. Cet article examine l'utilisation par la série de la ville réelle de Lappeenranta pour élaborer un imaginaire géopolitique sur lequel repose le récit. L'étude d'éléments caractéristiques tels l'eau, la cave, le moulin à vent, la mairie à tous les niveaux (local, régional, étatique, national) permet d'interroger la construction narrative, dramaturgique, et visuelle d'une ville frontière chimérique superposée en filigrane sur les contours de la ville réelle. Nourrie par une visite des lieux de tournage en juin 2018, cette recherche emprunte à la géographie culturelle et à la théorie critique des relations internationales et des études télévisuelles pour comprendre l'influence de cette ville-frontière fictionnelle (Bordertown) sur la géopolitique vécue et incarnée au quotidien dans la petite ville de Lappeenranta.

\section{INDEX}

Mots-clés: Finlande, frontières, Polar Nordique/Nordic Noir, géopolitique, Bordertown

Keywords: Finland, borders, Nordic noir television, geopolitics, Bordertown

\section{AUTHOR}

\section{ROBERT A. SAUNDERS}

Robert A. Saunders is a Professor in the Department of History, Politics and Geography at Farmingdale State College-SUNY. He is the author of five books, including Geopolitics, Northern Europe, and Nordic Noir (Routledge, 2020). His research explores the changing nature of national, religious, and political identity in the late 20 th and early 21 st centuries. 
Robert A. Saunders est professeur au département d'histoire, de sciences politiques et de géographie de l'Université de New York, campus de Farmingdale (SUNY Farmingdale). Il est l'auteur de cinq ouvrages dont Geopolitics, Northern Europe, and Nordic Noir (Routledge, 2020). Ses recherches portent sur les évolutions de l'identité nationale, religieuse et politique au tournant du XXIe siècle. 